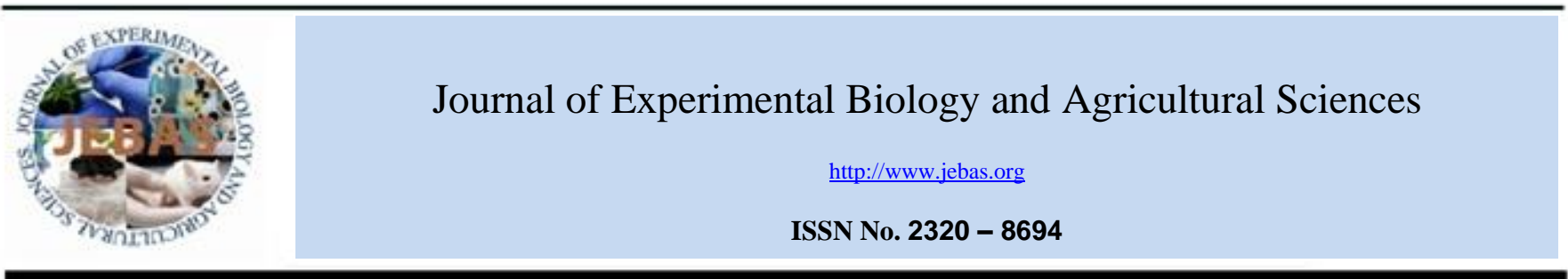

\title{
ASSESSMENT OF IL-33, TNF- $\alpha$ AND LEUKOTREINS B4 IN PATIENTS SERUM WITH ENTERIC FEVER
}

\author{
Khalil Ismail A. Mohammed*, Saad Hasan Mohammed Ali, Suha A. Al-Fukhar, \\ Wifaq M. Ali Al-Wattar, Jinan M. Mousa
}

Clinical Communicable Diseases Research Unit, College of Medicine, University of Baghdad, Baghdad, Iraq

Received - August 22, 2021; Revision - November 04, 2021; Accepted - December 24, 2021

Available Online - December 30, 2021

DOI: http://dx.doi.org/10.18006/2021.9(6).851.854

\section{KEYWORDS}

Salmonellosis

Interleukin-33

Tumor necrosis Factor $-\alpha$

Leukotreins B4

\begin{abstract}
Salmonella typhoid and paratyphoid are transmitted mainly by the fecal-oral route. This study was designed to find the correlation between Salmonella and IgM, IgG, and the levels of interleukin-33, TNF- $\alpha$, and LTB 4. The study was carried out from March 2020 to January 2021 for the detection of Salmonellosis in 100 suspected patients with age group ranging from 17 - 69 years, who attended Baghdad teaching hospitals that had been examined and defined as suspected cases by a specialized physician with the recording of clinical manifestation. The diagnosis was done by immunochromatography method, a blood sample was taken from the patient as well as other 30 healthy controls matching in age and gender. The study included measurement of the level of interleukin -33, Tumor necrosis Factor $\alpha$, and Leukotreins B4 level in sera of patients and healthy control. The results indicated that anti -salmonella IgM positive in 54 cases, anti- salmonella IgG positive in 46 cases, and 18 positive cases with both IgM and IgG. The Level of interleukin 33, Tumor necrosis Factor $-\alpha$ increased significantly while the serum Leukotreins B4 level decreased significantly in patients sera as compared with healthy control.
\end{abstract}

* Corresponding author

E-mail: dr.khalilmohammed1967@gmail.com (Khalil Ismail A. Mohammed)

Peer review under responsibility of Journal of Experimental Biology and Agricultural Sciences.

Production and Hosting by Horizon Publisher India [HPI] (http://www.horizonpublisherindia.in/).

All rights reserved.
All the articles published by Journal of Experimental Biology and Agricultural Sciences are licensed under a Creative Commons Attribution-NonCommercial 4.0 International License Based on a work at www.jebas.org.

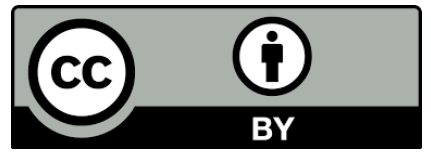




\section{Introduction}

Salmonella typhoid and paratyphoid are transmitted mainly by the fecal-oral route, it can excrete large numbers of organisms in the stool and contaminate food or water, either through direct food handling, or through flies and other insects, or by contamination of potable water and raw frozen chickens meat (Nader et al., 2015).

Salmonella initially interacts with epithelial cells, which can recognize pathogenic bacteria and initiate an inflammatory response and recruit a variety of Peyer's patches (PPs) phagocytes (Kaiser \& Hardt, 2011). The immune response to Salmonella in mesenteric lymph nodes (MLNs) involves the recruitment of neutrophils and inflammatory monocytes, these responses are important for delaying the spread of bacteria to systemic tissues (Rydstrom \& Wick, 2007). In addition, resident macrophages within the infected tissues can also phagocytose bacteria and recognize cytosolic flagellin via the NLRC4 inflammasome complex to activate caspase-1 and induce pro-inflammatory cytokines IL-1 $\beta$ and IL-18 (Broz et al., 2010).

SCs residents can organize flagellin and lipopolysaccharide for the Salmonella causing increases in the expression of CD40, CD86, CD80, and CCR7 (Miao et al., 2006), this can enhance the capabilities of the antigen and allow the T-Cell migration to start and initiate the adaptation of the response of the immune system (Salazar-Gonzalez et al., 2007).

The activation of immune responses in the mucosa and the resulting inflammation serves as an activator of further innate immune responses. One of these is the recruitment of neutrophils to the mucosa, which is mostly mediated via the IL-23/IL-17 axis. The production of IL-17 stimulates the secretion of CXC chemokines by intestinal epithelial cells and granulopoiesis in the bone marrow by inducing the production of G-CSF (granulocyte colony-stimulating factor) (Raffatellu et al., 2008). IL-1 $\beta$ production could also contribute to neutrophil recruitment, since Caspase-1-deficient mice exhibit reduced levels of CXC chemokines in the cecal mucosa early after $S$. typhimurium infection, the recruitment of neutrophils is crucial to prevent the dissemination of Salmonella from the gut since neutropenia increases the risk of systemic infections (Agostini et al., 2004). The current study was carried out to assess the level of IL-33, TNF- $\alpha$, and Leukotreins B4 in patients serum with Enteric Fever

\section{Materials and Methods}

The current study was carried out from March 2020 to January 2021, the study was involved suspected patients between the age ranges of 17-69 years. Blood samples were collected from the 100 clinically Salmonellosis suspected patients and 30 healthy individuals with the same age groups.

\subsection{Blood samples}

Five $\mathrm{mL}$ of venous blood was obtained from each patient and collected in a sterilized screw cap plastic tube, these blood samples were left for 30 minutes at room temperature, then centrifuge at $3000 \mathrm{rpm}$ for five minutes, then the serum for each sample was collected in Eppendorf tubes and test for Salmonellosis (IgM and IgG) and stored in deep freeze at $-20{ }^{\circ} \mathrm{C}$ until the completion of the study.

\subsection{Immunochromatographic assay}

This CerTest-salmonella is a kit that qualitatively determines the presence of salmonella in blood samples. $100 \mu \mathrm{l}$ of serum from each sample was added to the sample hole of the kit. The color density is proportional to the antibody titer. The complexes (appears in the color band after 10 minutes) confirm that the test was performed correctly. In positive results, certain antibodies that have existed on the membranes captured these particles which lead to the appearance of a red-tinted line that can be observed while the other result appears in a green-tinted line (the negative results that represent the control samples).

\subsection{Immunological tests}

The level of interleukin-33 (Peprotech, USA), Tumor necrosis Factor- $\alpha$ (Peprotech, USA), and Leukotreins B4 (CreativeDiagnostic) was estimated by ELISA according to the manual standard procedure.

\subsection{Statistical Analysis}

The results were analyzed using the statistical system SPSS version -18

\section{Results}

\subsection{Serological tests}

Among the collected 100 serum samples, the level anti-salmonella IgM was reported in 54 cases, while the level of anti-salmonella IgG was reported in 46 cases. While the level of both IgG and IgM was reported in 18 cases (Table 1).

\subsection{Immunological parameters}

In the case of the IL-33, and TNF- $\alpha$, these parameters were increased significantly $(\mathrm{p} \leq 0.05)$ in patients suffering from Salmonellosis (192.73 \& $223.30 \mathrm{pg} / \mathrm{ml}$ respectively) as compared to the healthy individual $(38.50 \& 141.50 \mathrm{pg} / \mathrm{ml}$ respectively). While in the case of serum LTB4 $(\mathrm{pg} / \mathrm{ml})$ concentration, it decreased significantly in patients' groups in comparison with healthy control (Table 2). 
Table 1 Distribution of anti-Salmonella IgG and IgM antibodies using immunochromatography method

\begin{tabular}{|cccc|}
\hline Anti-salmonella antibodies & Total & Positive $(\mathrm{N} \%)$ & Negative (N\%) \\
\hline $\operatorname{IgG}$ & 100 & 46 & 54 \\
\hline $\operatorname{IgM}$ & 100 & 54 & 46 \\
\hline $\operatorname{IgG}+\operatorname{IgM}$ & 100 & 18 & 828 \\
\hline
\end{tabular}

Table 2 Concentration of Interleukins-33, Leukotreins B4 and TNF- $\alpha$ level in healthy and patients with Salmonellosis

\begin{tabular}{|c|c|c|c|}
\hline Groups & IL-33 (pg/ml) & LTB4 (pg/ml) & TNF- $\alpha(\mathrm{pg} / \mathrm{ml})$ \\
\hline Patients & $192.73 \pm 8.54$ & $23.60 \pm 4.80$ & $223.30 \pm 48.43$ \\
\hline Control & $38.50 \pm 2.80$ & $35.50 \pm 2.63$ & $141.50 \pm 2.80$ \\
\hline
\end{tabular}

\section{Discussion}

Salmonella can colonize and cause infections in both humans and animals. Of interest, some Salmonella species appeared to be better adapted to humans, and vice versa. For example, S. typhi does not have an animal reservoir and is solely transmitted by humans. Most human cases of Salmonella involve ingestion of a contaminated food item, in particular, eggs, poultry, ground beef, or dairy products (Miao et al., 2006). Further, Salmonella can be acquired by direct personal contact, nosocomial transmission, or contaminated drugs/solutions (Awad \& Ghareeb 2014).

The results of the current study indicated the presence of antisalmonella $\operatorname{IgG}$ and $\operatorname{IgM}$ ( $46 \%$ \& 54\% respectively) in the patients suffering from Salmonellosis by immunochromatography method (Table 1). Generally, the prevalence of infection is related to various factors including nutritional habits (Awad \& Ghareeb, 2014). The increasing level of IL-33 in patients with Salmonellosis as compared to the healthy control might be due to the ability of salmonella to up-regulate Th2 and downregulate Th1 (Prefontaine et al., 2009). Furthermore, DePaolo et al. (2005) suggested that INF- $\gamma$ is involved in the clearance of infection and correlated with the protection from Salmonellosis infection. The decreasing level of Leukotreins B4 in patients of Salmonellosis in comparison with healthy control in all interval ages may be due to the bacteria altering or failing to activate the 5-Lipoxygenase pathway in humans monocyte. The suppression of the 5-Lipoxygenase pathway could be involved in the survival of the bacteria as LTB4 induce neutrophil activation and degranulation through its effects on the $\beta$ isoform of phosphoinositide 3-kinase and the Src kinase, respectively (Kulkarni et al., 2011).

LTB 4 activates the GTPase Rac and Rac-extracellular signalregulated kinase, two signaling molecules that contribute to phagocytosis and chemotaxis (Woo et al., 2002). TB 4 is also involved in increasing the sensitivity of T lymphocytes to IL-2, a mediator essential for $\mathrm{T}$ cell proliferation. Also, LTB 4 increased the sensitivity of cytotoxic lymphocytes to IL-2 activation, this increased activity was attributed to an upregulation of IL-2 receptor $\beta$ expression, which is mostly expressed on natural killer and CD8 T cells. The increasing level of TNF- $\alpha$ may be produced mainly by activated antigen-presenting cells or activated macrophages involved in mediating host defense mechanisms against facultative intracellular pathogens, and septic shock caused by bacterial LPS as the TNF- $\alpha$ can enhance the resistance of the host to infection (Matsui \& Arai 1992). Although LPS is considered the most potent inducer of TNF- $\alpha$, purified Salmonella porins have also been shown to trigger activation and cytokine production in human monocytes (Matsui \& Arai, 1992).

\section{Conclusion}

The results of the current study indicated the presence of antisalmonella IgM positive in 54 cases, anti- salmonella $\operatorname{IgG}$ positive in 46 cases, and 18 positive cases with both IgM and IgG. The Levels of interleukin- 33, TNF- $\alpha$ increased significantly while the serum LTB 4 decreased significantly in patients sera in comparison with healthy control.

\section{Conflict of interest}

No conflict of interest

\section{Funding}

No source of any funding

\section{References}

Agostini L, Martinon F, Burns K, McDermott MF, Hawkins PN, Tschopp J (2004) NALP3 forms an IL-1beta-processing inflammasome with increased activity in Muckle-Wells autoinflammatory disorder. Immunity 20(3): 319-325.

Awad WA, Ghareeb K (2014) Some aspects of control of salmonella infection in poultry for minimizing contamination in the food chain. Worlds Poultry Science Journal 70: 519-530. 
Broz P, Newton K, Lamkanfi M, Mariathasan S, Dixit VM, Monack DM (2010) Redundant roles for inflammasome receptors NLRP3 and NLRC4 in host defense against Salmonella. Journal of Experimental Medicine 207(8): 1745-1755.

DePaolo RW, Lathan RJ, Ollins RB, Karpus WJ (2005) The Chemokine CCL2 Is Required for Control of Murine Gastric Salmonella enteric Infection. Infection and Immunity 73(10): 6514-6522.

Kaiser P, Hardt WD (2011) Salmonella typhimurium diarrhea: switching the mucosal epithelium from homeostasis to defense. Current Opinion in Immunology 23(4): 456-463.

Kulkarni S, Sitaru C, Jakus Z, Anderson KE, Damoulakis G, Davidson K, et al. (2011) PI3Kbeta plays a critical role in neutrophil activation by immune complexes. Science Signaling 4 : ra23.

Matsui K, Arai T (1992) The comparison of cell-mediated immunity induced by immunization with porin, viable cells, and killed cells of Salmonella typhimurium. Microbiology and Immunology 36: 269-278.

Miao EA, Alpuche-Aranda CM, Dors M, et al. (2006) Cytoplasmic flagellin activates caspase-1 and secretion of interleukin 1beta via Ipaf. Nature Immunology 7(6): 569-575.
Nader MI, Rasheed MN, Hammed HH (2015) Molecular Identification of Salmonella, Cellular \& Molecular Biology, Pharmaceutical \& Food Sciences (GCMBPF-2015) June 5-6, 2015 Istanbul: Pp.118-120

Prefontaine D, Lajoie-Kadoch S, Foley S, Audusseau S, et al. (2009) Increased expression of IL-33 in severe asthma: evidence of expression by airway smooth muscle cells. Journal of immunology 183: 5094-5103.

Raffatellu M, Santos RL, Verhoeven DE, George MD, Wilson RP, Winter SE, et al. (2008) Simian immunodeficiency virus-induced mucosal interleukin-17 deficiency promotes Salmonella dissemination from the gut. Nature Medicine 14: 421-428

Rydstrom A, Wick MJ (2007) Monocyte recruitment, activation, and function in the gut-associated lymphoid tissue during oral Salmonella infection. Journal of Immunology 178(9): 5789-5801.

Salazar-Gonzalez RM, Srinivasan A, Griffin A, et al. (2007) Salmonella flagellin induces bystander activation of splenic dendritic cells and hinders bacterial replication in vivo. Journal of Immunology 179(9): 6169-6175.

Woo CH, You HJ, Cho SH, Eom YW, et al. (2002) Leukotriene B(4) stimulates Rac-ERK cascade to generate reactive oxygen species that mediates chemotaxis. Journal of Biological Chemistry 277: 8572-8578. 